\title{
Essay
}

\section{Norwegian Taxi Industry Through 2020}

\author{
Sigurd M. N. Oppegaard \\ University of Oslo \& Fafo, Institute for Social and Labour Research
}

The year 2020 was scheduled to become the year of far-reaching changes in the regulation of the Norwegian taxi industry. As the year progressed, and the Covid19 pandemic unfolded, it turned out more dramatic than anyone could have foreseen. This essay offers a brief overview of the history and organisation of the Norwegian taxi industry, followed by findings from a research project, where we, among other things, explored how taxi owners and drivers in Norway experienced 2020. ${ }^{1}$

\section{A Brief History of Taxis in Norway}

The precursor to the Norwegian taxi industry was the skyss or shuttle system in the middle ages, which required farmers to provide the king, nobility, clergy and highlevel bureaucrats with free transportation to the next farm when they traveled across the country - in exchange for certain tax exemptions. In 1816, the skyss system was abolished, and travellers had to pay for transportation; a network of coaching inns was established to organise lodging and transport. In the cities, the coachmen guilds operated transportation by horse-drawn vehicles from their homes and later cabstands, with fares and market entry regulated by the police. These early taxis primarily serviced the upper classes and tourists. Cars were in-

\footnotetext{
1 The analysis is based on data collected through a project mapping the consequences of the new taxi market regulation for the Norwegian taxi industry. The project is led by the Institute of Transport Economics (TØI) and Fafo. See Aarhaug et al. (2020) for the first report from the project and empirical basis for this essay.
} 
troduced in the early $20^{\text {th }}$ century, and taximeters were required to determine the price of each ride. In 1926, the municipalities started means-testing taxi licenses. ${ }^{2}$

In the subsequent decades, taxi owners - those who own a taxi and hold a taxi license - enjoyed a relatively high status in Norway, on a par with independent artisans. ${ }^{3}$ They were their own boss, earned a decent income, and had substantial flexibility in their work arrangement. As the owners of their business, they drove their cars, were responsible for acquiring rides, and organising payment and maintenance. Rides were allocated at the cabstand, following an informal but highly institutionalised system where the first taxi in line took the first customer. In the post-war period, dispatching centres became increasingly important in the organisation of the Norwegian taxi industry - they controlled the booking and distribution of rides, and they could require drivers to accept rides. Taxi owners, while still formally self-employed, became dependent on dispatching centres, as an increasing number of rides was ordered through these. This entailed deskilling (Braverman, [1974]1998); many of the taxi drivers' skills and competencies - acquiring customers and organising their workday in particular - were transferred to the dispatching centres and their technology.

The post-war period also saw taxi owners employing drivers to take shifts, driving their car to a greater extent. ${ }^{4}$ Today, there are approximately 7000 employed taxi drivers and just below 6000 taxi owners in Norway. The drivers hired by the taxi owners thus constitute a significant proportion of the labour force in the industry. They are classified as employees of the taxi owners' sole proprietorships and earn a commission from the fare of each ride. ${ }^{5}$ However, the relationship between the taxi owner and the employed drivers is not merely an economic relationship between employer and employee, but in practice is reminiscent of one between a master and an apprentice, as the employed drivers often are in line to receive a taxi license of their own. Furthermore, it is also relatively common for taxi owners to hire family members and friends to drive their car.

The post-war period generally saw the status of taxi drivers decline. There are several interconnected reasons for this, and I will present a few hypotheses. The dispatching centres' increased control over the drivers' labour processes, and the normalisation of use of employed drivers has transformed the occupation. From having been independent small business owners with substantial autonomy and freedom, driving a taxi looked more and more like regular wage-labour. Taxi services as a commodity went from being a luxury good in the early $20^{\text {th }}$ century, re-

\footnotetext{
2 The means-testing of taxi licenses allows the municipalities to decide how many taxis that can operate within a specific area based on the demand for taxi services.

3 This exposition is primarily based on Steen (1988).

4 While taxi owners are required to have a taxi license, drivers need a professional license. The latter, in contrast to taxi licenses, are not means tested.
}

5 41,8 percent if they follow the collective agreement. Many, however, do not. 
served for a small segment of the population, to being available to new groups of consumers, in tandem with increasing prosperity. The supply-side of the taxi market was hence adjusted to these new consumption patterns and customers. The aura of luxury began to disappear as exclusive cars were replaced by fuel-efficient vehicles and the drivers' uniforms became less formal; the drivers lost the status derived from providing a luxury service. The exclusivity of taxi drivers' competence was further challenged by the normalisation of driver's licenses (Davis, 1959) and by technological developments in GPS systems that made driving taxis less dependent on knowledge of local geography. Furthermore, one can assume that changes in the industry's labour force were an important factor contributing to its declining status. Today, the industry is largely composed of firstgeneration immigrants, and offers one of the few jobs in the Norwegian labour market where people with limited language skills can earn a living (Brox, 2016).

\section{Towards Deregulation}

In November 2014, the American transportation platform Uber started operating in Oslo (Oppegaard, 2018, 2020), launching two services: Uber Black and Uber Pop. Uber Pop was launched as a trial project, first for a few selected users but soon made generally available. The service allowed everyone with a less than tenyear-old car to sign up and become Uber drivers. However, since the regulation of the Norwegian taxi market requires drivers to have a taxi license, 138 drivers were fined, 94 lost their driver's license, and 67 got their earnings confiscated throughout 2016 and 2017. In addition, Uber Norway and Uber's Dutch subsidiary received a NOK 5 million fine in September 2017, and Uber Pop was discontinued a few weeks later.

Uber Black, on the other hand, continued operating. This service is organised through limousine companies who owned the cars and employed the drivers. Uber Black is a high-end service, and the cars are licensed with a specific type of license for exclusive passenger transportation. In the luxury segment of the Norwegian taxi market, Uber - assisted by limousine companies - thus found an opportunity to provide transportation services in Norway despite the tight taxi market regulations.

Uber's attempt to establish its preferred model in Oslo - one where everyone can easily sign up to become drivers - reignited a debate on how the Norwegian taxi market should be regulated. The Consumer Council and Competition Authority argued that the means testing and numerical restriction on licenses led to high prices, poor service, and an inefficiently organised industry. In early 2017, a government-appointed commission published a report on the so-called sharing economy in Norway (NOU 2017:4), proposing to remove the means testing of and numerical restrictions on taxi licenses. The same year, the EFTA Surveillance Authority argued that the regulation of entry to the taxi market was a breach of Norway's obligation under the EEA agreement to facilitate freedom of establishment. In 2018, the Ministry of Transport and Communications proposed a new 
taxi market regulation aimed at facilitating new business models and increased competition in the taxi industry, by, among other things, removing the numerical restrictions on taxi licenses.

In June 2019, the parliament voted to remove numerical restrictions on licenses and the taxi owners' duty and right to be connected to a dispatching centre, and to transfer qualification requirements from license holders to the drivers. Additionally, there was an aim to remove the taximeter requirement, but a functioning replacement is yet to be decided on (Oppegaard, Saari \& Saloniemi, 2020). The changes were scheduled to take effect from July 1, 2020.

\section{A Dual Crisis}

Initially, 2020 was predicted to become a difficult year for the Norwegian taxi industry. According to drivers, the demand for taxi services and the profitability of taxi operations has been decreasing steadily over the last decade, and they spent more and more of their working day waiting for requests. Generally, drivers work between 10 and 14 hours, six days per week. Their income is based solely on how many customers they serve, and in 2019, the median monthly income of employed taxi drivers was NOK 32960 before taxes. ${ }^{6}$ Taxi owners, who take a substantial cut of the money their drivers collect, earn more, but they also have to cover the operation's costs - such as fuel, service, employer's tax, pensions, insurance, and fees to the dispatching centre.

When the deregulation process started, anxiety and insecurity spread across the industry. The primary objectives of the new regulations were to increase competition in order to lower the prices of taxi services and facilitate the emergence of new business models; the drivers' working conditions and pay were more or less a non-issue. Taxi owners and drivers were particularly sceptical of the 'hobbyfication' of the industry - of allowing people to drive a taxi whenever they have a few hours to spare. To be always available for customers has been an important ethos of the Norwegian taxi industry, ${ }^{7}$ and they see themselves as an integral part of Norway's transportation network. The lowering of the barriers of entry would let almost everyone become taxi drivers, without regard to their qualifications, which, according to the taxi drivers would lead to poorer quality, particularly for vulnerable customer groups, such as elderly and disabled people. ${ }^{8}$ They also feared that a new group of taxi drivers would enter the market: independent taxis ${ }^{9}$ - not con-

\footnotetext{
6 Based on data from Statistics Norway. As a comparison, the average monthly wage in Norway in 2019 was NOK 47 290, while workers in adjacent industries, bus and truck drivers, on average earned NOK 36690 and 37540 respectively.

7 The motto of the taxi owners' association, Norges Taxiforbund, is 'taxi-everywhere, always.'

8 In Norway, the taxi industry sells transportation services for such groups to the government, driving children with special needs, elderly, and so on.

9 Often referred to as "friåkare," the Swedish name for this taxi category.
} 
nected to a dispatching centre - who can set their own fare, much higher than the traditional taxis if they want, and thus potentially contributing to reducing the customers' trust in the industry, resulting in a further decline in the occupation's status.

Two and a half months into 2020, the Covid-19 pandemic hit. Taxi drivers in Oslo might have been among the first to be infected by the disease, as they were the ones who drove the first Covid-19 cases in Norway, tourists who had spent their winter holidays skiing in Austria and Italy, home when they landed at the airport. ${ }^{10}$ In the subsequent weeks, demand for taxi services decreased dramatically. Some areas reported a fall of up to 90 percent. As one of the taxi owners we interviewed said, 'it was like the air left the balloon, it was punctured within one or two days.' As travel and tourism were suspended, meetings digitalised, homeschooling implemented, and mobility reduced, people were no longer using taxis. The majority of the employed drivers were temporary laid off during the spring of 2020.1 ${ }^{11}$ They thus received unemployment benefits, 62,4 percent of their previous pre-taxation income, which, although it was a substantial reduction, probably constituted more money than they, as paid on commission, would have earned if they had continued to drive in the pandemic-ridden taxi market. ${ }^{12}$ The license holders, as self-employed small business owners, do not have the same rights to unemployment benefits, but many applied for income-loss compensation. However, the schemes were adjusted to large entities with high revenue and fixed costs, and while the license holders who own multiple cars were able to get some compensation, single-car owners did not receive much.

There were also drivers and taxi owners who worked throughout the pandemic. They had to wait hours between each ride: 'I sit and wait seven-eight hours, maybe I make a few hundred kroner,' one license holder told us. During the pandemic, the market shifted towards shorter rides - from customers traveling to the airport to customers preferring to take a taxi instead of bus when going shopping. Thus, when the drivers eventually got a customer, the rides were often not very lucrative. The pandemic also had psychological effects on many drivers, who were scared of being infected or of infecting customers. The situation improved during the summer. While the initial phase had resulted in an abrupt stop, many of the laid-off drivers were back on the road by September: 'We have no passengers in the front seat, but we are back to normal now,' one driver said. Although back at work, the demand was still low and the wait between customers long, often four or five hours.

\footnotetext{
10 https://www.aftenposten.no/norge/i/GGLm4J/taxisjaafoer-mohammed-egeh-havnet-paa-intensiven-etter-aa-ha-blitt-smittet

11 As one the emergency measures enacted by the government, it was made easier and cheaper for employers to temporary lay off workers.

12 However, the piecework system made it difficult for some drivers to receive the benefits to which they were entitled.
} 
Some of our interviewees told us they lost money driving in 2020, as their income could not cover their fixed costs. A few of the owners we talked to said they had to take a loan from friends and family to keep the business running. And although the pandemic produced dire situations, many highlighted that 2019 had been a terrible year too: 'It is too much competition in the taxi market. Not only are there too many taxis, but we are in competition with buses, metros, trains and so on, too.' Combined with the coming deregulation, the pandemic led taxi owners to hand in their licenses and drivers to quit. ${ }^{13}$

\section{The Road Ahead}

For the Norwegian taxi industry, the road ahead is foggy. Those earning their living by driving taxis cannot see many weeks ahead into the future. Deregulation and the removal of numerical restrictions on licenses and of owners' duty and right to be connected to a dispatching centre, were initially scheduled to take effect on 1 July but were postponed until the 1 November due to the pandemic. On 2 November, Uber launched two new services in Oslo, Uber X and Uber Green. ${ }^{14}$ Since the taximeter requirement is not removed yet, Uber cannot operate the model where everyone can use their private car to drive Uber customers; instead, Uber extended the model used for Uber Black in Oslo, where limousine companies provide licensed cars and drivers. Regular taxi drivers have also started driving for Uber in addition to dispatching centres. ${ }^{15}$ However, as the taximeter requirement is scheduled to be replaced by digital equivalents, ${ }^{16}$ these arrangements might only be temporary fixes on the path towards full deregulation.

For the Norwegian taxi industry, 2020 represented a dual crisis, although the last decade has by no means been rosy. On the one hand, the deregulation rearranged the organisation of the industry, allowing, among others, Uber to expand its operations and independent taxi owners to provide rides without being connected to a dispatching centre. In an industry where many already struggle, partially due to oversupply, the short-term effects of the lowered barriers to entry might be fewer customers per taxi and reduced income. On the other hand, the Covid-19 pandemic led to a dramatic fall in demand for taxi services and an economically desperate situation for many owners and drivers. In face of these challenges, many have considered leaving or already left the industry - without, however, many

\footnotetext{
13 We do not yet have number on how many exited the industry in 2020.

14 Uber Green is a service where all cars are electric.

15 https://e24.no/naeringsliv/i/GaP84J/taxisjaafoerer-kjoerer-uber-paa-si-det-boer-ikke-vaere-lov-deter-urettferdig?referer=https\%3A\%2F\%2Fwww.vg.no

16 https://www.regjeringen.no/contentassets/bb9745a9998c494fbb22bb29bf17b867/horingsnotat-taksameter.pdf
} 
places to go. ${ }^{17}$ Today, the industry is primarily composed of people who have been driving taxi for most of their careers and of immigrants with limited Norwegian language skills and formal qualifications. In an already tight and crisis-laden labour market, their prospects might become even bleaker.

\section{References}

Aarhaug, Jørgen; Oppegaard, Sigurd M. N.; Gundersen, Frants H.; Hartveit, Knut J. L.; Skollerud, Kåre H. and Dapi, Bjorn. 2020. Drosjer $i$ Norge fram mot 2020 [Taxis in Norway towards 2020]. TØI report 1802/2020/Fafo report 2020:24. Oslo: Institute of Transport Economics/Fafo. https:// fafo.no/images/pub/2020/20759.pdf

Braverman, Harry. [1974]1998. Labor and Monopoly Capital. The Degradation of Work in the Twentieth Century. New York: Monthly Review Press.

Brox, O. 2016. På vei mot et postindustrielt klassesamfunn? [Towards a post-industrial class-society?] Oslo: Pax.

Davis, Fred. 1959. "The cabdriver and his fare: Facets of a fleeting relationship." American Fournal of Sociology, 65, 158-165. https://cpb-us-e2.wpmucdn.com/sites.uci.edu/dist/a/2250/files/2015/08/Davis_TheCabdriver_AJS_1959.pdf

NOU 2017:4. Delingsøkonomien - muligheter og utfordringer [The Sharing Economy Opportunitets and Challenges]. Oslo: Ministry of Finance. https:// www.regjeringen.no/contentassets/1b21 cafea73c4b45b63850bd83ba4fb4/no/pdfs/nou201720170004000dddpdfs.pdf

Oppegaard, Sigurd M. N. 2018. The Strains of Luxury. Labor in the Platform Economy. The Case of Uber Black in Oslo. MA thesis. Oslo: Department of Sociology and Human Geography, University of Oslo. https://www.duo.uio.no/bitstream/handle/10852/66486/Oppegaard-2018-The-Strains-of-LuxuryMaster-s-Thesis.pdf? sequence $=1$ \&isAllowed $=\mathrm{y}$

Oppegaard, Sigurd M. N. 2020. "Regulating Flexibility: Uber's Platform as a Technological Work Arrangement." Nordic Journal of Working Life Studies, https://doi.org/10.18291/njwls.122197

Oppegaard, Sigurd M. N., Saari, Tiina \& Saloniemi, Antti. 2020. Uber's trajectories in the Nordic countries. In: Kristin Jesnes and Sigurd M. N. Oppe-

\footnotetext{
17 We even heard stories of drivers planning to leave Norway. One of these drivers told us he came to Norway with a master's degree from his home country, but started as a taxi driver when it turned out he could not get the job he had hoped in Norway. Now, he thought it would be impossible to earn a living driving taxi and saw no reason to stay here.
} 
Sigurd M. N. Oppegaard-Norweegian Taxi Industry Through 2020

gaard, Eds. Platform Work in the Nordic Models. Issues, Cases and Responses. Temanord 2020: 513. Copenhagen: Nordic Council of Ministers, pp. 25-46. DOI: 10.6027/temanord2020-513 https://pub.norden.org/temanord2020-513/\#25177

Steen, Arild H. 1988. Drosjeneringen: fra laug til industri? [The Taxi Industry: From Guild to Industry?] Oslo: University of Oslo. 